This pdf is a copy of a finally submitted Chapter to:

\title{
Southern African Landscapes and Environmental Change
}

\section{Edited by Peter J. Holmes and John Boardman}

Published by Routledge London 2018

ISBN: 978-1-138-68895-7 (hbk)

ISBN: 978-1-315-53797-9 (ebk)

Chapter 13 Monitoring and assessing land degradation: New approaches pp 249-274

\author{
Ian D.L. Foster and John Boardman
}

\section{Introduction}

In this chapter we consider the important topic of land degradation in southern Africa. We confine our comments to the major issue of erosion by water at scales ranging from a few square metres to assessments that aim to cover the whole region. We consider approaches to measure and reconstruct both current and historical erosion rates, focusing on the period since the arrival of Europeans who brought many of their farming and management practices with them. In most parts of the country, the impact of humans on the landscape has been readily apparent for the last 200 years. We regard this as 'accelerated erosion', i.e., erosion at rates well above natural geological norm for the current climatic conditions. A major challenge is putting current erosion in the context of what has gone before to answer the question: are things getting worse? The 'new approaches' of our title, are in 
some cases innovatory, and in others, approaches that have not been used in southern Africa previously. We consider direct measurement, remote sensing, fingerprinting and modelling as approaches to the monitoring and assessment of land degradation.

\section{Hillslope erosion: measurement, mapping and modelling}

Several recent publications have reviewed aspects of land degradation at the national scale for South Africa. Garland et al. (2000) pull together much work at the experimental plot scale on erosion under different land uses. Plot-based data quoted by Laker (2004) and Garland et al. (2000) make the obvious point that, in arable areas, erosion rates on different crops vary, with particularly high rates on maize, cassava and pineapples. The rates vary greatly with soil type (erodibility) and with management practices. For example, on maize, rates of $2500 \mathrm{t} \mathrm{km}^{-2} \mathrm{yr}^{-1}$ are 'commonly' recorded whereas, with debris left on the field to protect bare soil, the rates fall to below $200 \mathrm{t} \mathrm{km}^{-2} \mathrm{yr}^{-1}$. In contrast, rates on ungrazed veld are quoted by Garland et al. (2000) at $2.0 \mathrm{t} \mathrm{km}^{-2} \mathrm{yr}^{-1}$. Elsewhere, Strohbach (2002) reports observations made on 824 Namibian erosion plots, of which $11.9 \%$ show signs of moderate to severe sheet erosion or rill erosion and $9 \%$ of sites show signs of significant wind erosion. No recent plot studies have been obtained for other southern African countries from our literature search.

Because of the widely accepted limitations of the experimental plot approach, Garland et al. (2000) report on a nation-wide series of workshops at which the perceptions of Agricultural Extension Officers of the extent and scale of erosion were translated into maps based on Magisterial Districts. The work is extended and presented by Hoffman and Ashwell (2001). It is easy to be critical of such approaches (e.g. Le Roux et al., 2007: 'dependence on apparently subjective judgements'), especially in the light of the similar 
expert-based analysis at a global scale (GLASOD: Oldeman et al., 1991), which has been widely denigrated and misused. However, at the South African national scale, Hoffman and Ashwell (2001) has not been replaced by subsequent mapping or modelling, and the socioeconomic analysis accompanying this work is of value. An approach that also uses a qualitative assessment is that of Rowntree (2013). She reviews the early development of gullies ('sluits') using the evidence of newspapers and journals largely from the nineteenth century and reaches a similar conclusion to that of Boardman (2014) using ecological and geomorphological arguments.

Several studies have focused on the assessment of erosion and land degradation in other southern African countries. For example, Showers (1996) followed conventional procedures for environmental impact assessments in Lesotho which were modified to assess erosion mitigation methods used in the past. These Historical Environmental Impact Assessments (HEIAs) provided information about undocumented environments, extended baselines for modern EIAs and helped to identify past failures in order to guide future rehabilitation programmes. Stringer and Reed (2007) integrated local and scientific knowledge bases together in order to assess the severity of land degradation in Botswana and Swaziland while more recently, Reed et al. (2013) have identified different sources of knowledge that could be managed effectively in order to improve local land degradation monitoring and assessment methods. Klintenberg and Seeley (2004) used local stakeholders to help define four primary land degradation indicators related to land degradation in Namibia: population pressure, livestock pressure, seasonal rainfall and erosion hazards. These indicators were calculated annually for the period 1971 - 1997. Annual land degradation risk maps were subsequently produced for the same period by combining the indicators. A time series analysis of results was undertaken at two sites and the analysis 
revealed a general increasing degradation trend but with different causes in the two regions. None of these studies, however, make quantitative assessments of erosion rates. The European Soil Data Centre (ESDAC, n.d.) has freely available erosion hazard maps for Botswana, Lesotho, Mozambique, Swaziland and Zimbabwe but again do not provide estimates of erosion rates.

Recent work in the Sneeuberg (Figure 13.1) is partially covered in sections on sediment yields from small catchments (see below). A focus of the work has been the monitoring of erosion rates on badland areas using erosion pins. Although badlands represent a small proportion of catchments in the area (4 - 15\%), they vary in the degree of connectivity to valley-bottom gullies and therefore in their ability to deliver sediment to gullies and farm dams (Figure 13.2a). Rates of erosion have been monitored for 16 years and are, by any standards, high, with average net values of 3.1 to $8.5 \mathrm{~mm} \mathrm{yr}^{-1}$ over ten sites (Boardman et al., 2015; Boardman and Favis-Mortlock, 2016; Boardman et al., 2017).

\section{<Figure 13.1 around here>}

Remote sensing as a tool for erosion mapping was used by Talbot (1947) in a classic study in the Swartland and Sandveld (Figure 13.1) to show the devastation caused by extensive wheat farming on slopes which had been previously grazed. The change had been encouraged by the passing of the Wheat Importation Restrictions Act in 1930. In a subsequent paper, Meadows (2003) updates the story using air photographs from 1974 and 1989 to show that the changing political climate and sensible conservation measures have grossly reduced the amount of erosion in the area. He also shows that future climate change will pose a threat to this area of arable farming. Sequential air photographs are used in the Peddie District, Eastern Cape, to monitor erosion and vegetation change (Kakembo, 2001; Kakembo and Rowntree, 2003). Similarly, Keay-Bright and Boardman (2006) show changes 
in erosion in the Sneeuberg between 1945 and 2002 but note that the visible gully networks have shown little change in extent over almost six decades.

Le Roux et al. (2007) place their hopes for the future in remote sensing and GIS at the regional scale using high resolution satellite images such as SPOT5 for the identification of gullies, if not finer scale erosional features. This approach is illustrated in Mararakanye and Le Roux (2012) with a gully location map for South Africa. This is a useful dataset. The main disadvantage is the inability to distinguish between active and inactive gullies. Counter-intuitively, Keay-Bright and Boardman (2006) found that gullies in the Sneeuberg acted as efficient networks for runoff and sediment transport and delivery but showed that there had been little change in the gully networks since 1945 . Thus, most sediment passing through the gullies was coming from degraded hillslopes rather than the gullies themselves (Figure 13.2b). This finding was later confirmed by the use of ${ }^{137} \mathrm{Cs}$ in several fingerprinting studies initially reported by Foster et al. (2007). In other parts of the country many gullies are clearly active at present.

\section{$<$ Figure 13.2 around here $>$}

Much of the experimental work in South Africa has been directed at improvements in the factors that drive the Universal Soil Loss Equation (USLE) and its derivatives. To the sceptical, this may be compared to attempting to fix a sinking ship. Le Roux et al. (2007) rightly remark on the sensitivity of RUSLE to the topographic factor (cf. criticism of the recent attempt to apply RUSLE to Europe: Evans and Boardman (2016)); their preference is to emphasise the erodibility of the soil, whereas much empirical evidence would suggest the importance of vegetation/crop cover in reducing or accelerating erosion rates.

The use of models for the prediction of soil erosion is given full coverage in Smith (1999), Laker (2004) and Le Roux et al. (2007). They review the application of the models, 
USLE or derivatives thereof, and the results are not encouraging. The usual difficulties of data acquisition, of scaling-up, of validation in the absence of field data, are noted as key reasons for poor model performance. Much of the criticism is in line with comments made by Boardman (2006) but it has to be said that, in the past decade, the hopes for significantly better 'process-based models' have not been achieved. A particular South African issue is that so much experimental data remains in non-peer-reviewed reports of governmental or university organisations. Laker (2004) also notes the lack of communication between geographers and soil scientists in the country who could collaborate more actively to obtain better estimates of erosion rates and information on land degradation.

Beyond South Africa, the region is quite poorly served by studies of land degradation. This is despite some evidence that suggests that Swaziland and Lesotho should be considered as 'global erosion hotspots' (Boardman, 2006). Chakela and Stocking (1988) suggested that Lesotho had the highest erosion hazard of any single country in central or southern Africa, a conclusion supported by the work and analysis of Showers $(1989,2005)$. For Swaziland, the case rests on studies by Mushala $(1988,1997)$, Mushala et al. (1997), Morgan et al. (1997), Felix-Henningsen et al. (1997), Morgan and Mngomezulu (2003) and WMS Associates (1988). There are no systematic, up-to-date, national surveys of these countries despite the perceived problems other than the ESDAC (n.d.) erosion hazard maps reported earlier.

\section{Fluvial sediment transport and sediment yields}

Sediment yields from river monitoring in South Africa have been reported by Dedkov and Mozzherin (1984; 3 sites) the FAO (2008; 1 site), Milliman and Farnsworth (2011; 12 sites), Rooseboom, (1978; 16 sites) and Scott et al. (1998; 7 sites), making up the 38 river-based 
sediment yields reported and summarised by Vanmaercke et al. (2014). Only three of the 38 sites (monitored by Scott et al., 1998) combined estimates of bedload and suspended load. In many cases, calculation procedures and data quality are unclear, although most seem to have used a combination of sediment rating curves and daily river discharge and, like estimates derived from reservoir surveys (138 sites believed by Vanmaercke et al. (2014) to have reliable data) very few data appear to be available for the twenty-first century. Many of the monitoring periods are un-reported by authors, limiting the value of many of these yield estimates.

Beyond South Africa the data are either non-existent in the Vanmaercke (2014) database (Namibia and Swaziland) or are less reliable. Botswana has only one reported measurement for an unknown monitoring period that was calculated from data of unknown quality. It is reported for a station at the inlet to the Okavango Delta and gives a very low sediment yield of $0.4 \mathrm{t} \mathrm{km}^{-2} \mathrm{yr}^{-1}$. In Mozambique, gauging stations on the Limpopo and Zambezi Rivers give sediment yield estimates of 80.5 and $36.9 \mathrm{t} \mathrm{km}^{-2} \mathrm{yr}^{-1}$ for an unknown monitoring period, and a yield of $134.5 \mathrm{t} \mathrm{km}^{-2} \mathrm{yr}^{-1}$ is reported for the Cahora Bassa Reservoir, but the Mozambique data are generally thought to be of poor quality. The Vanmaercke et al. (2014) database for Zimbabwe reports 28 reservoir surveys of variable quality for monitoring periods between the 1970 s and 1984 or for unknown monitoring periods. Here, reported sediment yields range from 10 to $704 \mathrm{t} \mathrm{km}^{-2} \mathrm{yr}^{-1}$. Sediment yields in the small mountain kingdom of Lesotho are reported for 16 gauging stations for monitoring periods between 1976 or 1978 and 1982. While not considered of very high quality, the data suggest that sediment yields range from $\sim 3$ (Bokong River at Bokong) to $2050 \mathrm{t} \mathrm{km}^{-2} \mathrm{yr}^{-1}$ (N. Phuthiatsana catchment at Mapoteng). Surprisingly, the Vanmaercke et al. (2014) database does not include the yield estimates reported by Chakela (1981) based on a combination of 
sediment discharge measurements and reservoir sedimentation rates for periods of one to two years in the late 1970s. Here, reported sediment yields are generally high and range from 220 to just under $2000 \mathrm{t} \mathrm{km}^{-2} \mathrm{yr}^{-1}$.

The range of yields reported by Vanmaercke (2014) for southern Africa appear to be reasonably consistent with the estimates of sediment yield published by Walling and Webb (1983) and later by Boucher and Weaver (1991). The Vanmaercke et al. (2014) study suggested rates based on river monitoring ranged between 750 and $1000 \mathrm{t} \mathrm{km}^{-2} \mathrm{yr}^{-1}$ in Lesotho and the Drakensberg Mountains to below $50 \mathrm{t} \mathrm{km}^{-2} \mathrm{yr}^{-1}$ in the drier interior of the Northern Cape and the Free State. Analysis of the Vanmaercke et al. (2014) data base for South African sediment yields (the largest and most reliable dataset) shows significant differences in yield estimates depending on whether river or reservoir data bases are used (Figure 13.3). However, Table 13.1 shows that most of the catchment areas in the rivers data base for South Africa (both mean and median values) are much larger than those in the reservoir data base suggesting that the differences are at least in part determined by the lower sediment delivery ratio of the larger river catchments.

Figure 13.3 around here

\begin{tabular}{lll} 
& \multicolumn{2}{c}{ Catchment area $\left(\mathrm{km}^{2}\right)$} \\
& Mean & Median \\
Rivers & 55181 & 4530 \\
Reservoirs & 2700 & 477
\end{tabular}

Table 13.1 Differences in catchment areas between the Vanmaercke et al. (2014) South African sediment yield data base for river and reservoir-based estimates of sediment yield including the Roxeni and Ganora data (see text for explanation) 
Sediment yields for rivers can be measured directly and usually monitor suspended sediment load and bedload. However, as noted above, there are only total sediment yield data (bedload + suspended load) for three rivers in the Vanmaerck et al. (2014) data base for southern Africa, which may also partially explain why the river estimates are generally lower. In a recent update of sediment yield information for South Africa, Msadala et al. (2011) provide detailed guidelines and recommendations for river-based sediment yield monitoring, including installation of the most technologically advanced systems for flow measurement in southern Africa in order to help validate their attempts to model sediment yields using several different modelling strategies (see modelling section) validated mostly on data derived from the earlier surveys of Rooseboom et al. (1992).

Installation of technologically advanced monitoring systems may be prohibitively expensive and difficult to maintain in remote parts of southern Africa. However a new methodology is being developed and tested in the heavily degraded Tsitsa River catchment in South Africa's Eastern Cape using trained and locally resident citizen technicians. The technicians carry out basic sediment sampling and measurement and results are validated in subsequent laboratory analyses. Measurements, photographs and observations are transmitted back to the science coordinating team using Open Data Kit-enabled smartphones to collect flood-focused suspended sediment samples that will be used to estimate sediment yields and target rehabilitation prior to the construction of a major reservoir (see Bannatyne et al., 2017).

It is evident that southern Africa is currently data poor in relation to erosion and sediment yield information, although techniques are available for collecting information at large and small catchment scales (e.g. using small farm dams in small catchments and large 
reservoirs for regional estimates of yield, coupled with long-term monitoring of large and small rivers). That current modelled estimates may be flawed was an issue raised by Rowntree (2012) who pointed out that the sediment yield of the Mfolozi river catchment reported by Rooseboom et al. (1992) from a reservoir resurvey was around $240 \mathrm{t} \mathrm{km}^{-2} \mathrm{yr}^{-1}$ whereas Grenfell and Ellery (2009) estimated the yield to be $\sim 60 \mathrm{t} \mathrm{km}^{-2} \mathrm{yr}^{-1}$, suggesting that the models used to extrapolate sediment yields downstream may not be able to cope with substantial sediment storage in the floodplains of large rivers. Such overestimates may be compounded by the variability in stream power caused by the presence of resistant dolerite intrusions reducing stream gradient (and stream power) in many large South African catchments and providing opportunities for major sediment stores to develop between the dolerite intrusions (see Tooth and McCarthy, 2007). An important recent contribution to the debate about rates and sources of sediment is made by Compton et al. (2010). They point out that the Orange River mud flux, prior to the building of large dams (1930 - 1969), is ten times greater than the mean Holocene value. They suggest that this implies a hundredfold increase in total soil erosion rates in recent times and that this increase is likely the result of intensive cultivation and heavily grazed areas within the Orange River catchment. Several authors implicate overgrazing as a key driver of land degradation in southern Africa (e.g. Beugler-Bell and Buch, 1997; Thomas et al., 2000; Strohbach 2002; Boardman et al., 2017) although overgrazing may not be the dominant cause in all cases (Rowntree et al., 2004). Despite several decades of effort, there is still uncertainty in exactly what sediment yields are for southern Africa or what the major sources and controls on sediment production are (e.g. Russow and Garland, 2000), yet the region is critically dependent on hundreds of large storage reservoirs for water supply and irrigation, many of which are filling up at rates far higher than those elsewhere in the world. That this fact has been 
known for some considerable time (e.g. Rooseboom, 1978; Boucher and Weaver, 1991) is even more concerning. The lifespan of reservoirs is dependent on the rates of hillslope erosion and sediment conveyance by rivers. Part of the long-term planning problem lies in not knowing how much sediment is being transported to reservoirs as this will define their useful lifespan. A secondary question, crucial for sediment management, is: Where is most of the sediment coming from? The significance of this question lies in being able to target scarce resources for mitigation to those areas where the greatest impact (measured as sediment yield reduction or increased lifespan of the reservoir) might be felt for the minimum cost. In a later section we explore new techniques in sediment fingerprinting that have been used effectively in many parts of the world but have only been tested in South Africa for little over a decade yet are beginning to show considerable promise.

\section{$<\mathrm{HA}>$ Palaeoenvironments and sediment yields change}

$<$ MTFO>Like many environments, southern African landscapes contain natural and artificially created sediment stores that preserve an archive of palaeoenvironmental conditions over a range of timescales. These occur as long-term features that have existed for centuries to millennia, such as alluvial and colluvial valley fills and river terraces (benches), or more transient features such as alluvial fans, wetlands, flood-outs, natural lakes and artificial reservoirs that may have existed for decades to centuries. The latter range in scale from small farm dams trapping sediment from catchments as small as a few hectares in area to major reservoirs draining hundreds of thousands of square kilometres like the Vanderkloof and Gariep dams located on the Orange River south of Bloemfontein. Many of these environments are not suitable for estimating sediment yield although other palaeoenvironmental data on land use change and climate can be determined from dating 
sediment cores and analysing preserved fossil pollen, fungal spore and charcoal remains that accumulate in such locations (e.g. Meadows \& Hoffman, 2002; Mighall et al., 2012). Many of these approaches are discussed in the fingerprinting section below. It has also been documented by Boardman and Foster (2011) that about a third of 100 dams surveyed in the Sneeuberg region of the Eastern Cape were either full of sediment or that the dam walls had been breached and remained unrepaired. Nevertheless, there is a large enough sample of un-breached and only partially filled dams in many locations in southern Africa where sediment yield and other data could be obtained over timescales of decades to centuries.

Estimates of catchment sediment yield can be obtained by measuring the total amount of sediment accumulating in natural or artificial reservoirs either since their date of formation or construction or between known dates of survey. Estimates of sediment density and trap efficiency (see Foster et al., 2008) are required for each reservoir in order to calculate sediment mass stored, and the sediment yield (in $\mathrm{t} \mathrm{km}^{-2} \mathrm{yr}^{-1}$ or $\mathrm{t} \mathrm{ha}^{-1} \mathrm{yr}^{-1}$ ) is estimated, assuming we know the catchment area and the number of years over which the sediment has accumulated. Such studies have been undertaken for many years in South Africa, including the early work of Rooseboom (1978; cited by Vanmaercke et al., 2014), Weaver (1989) and Boucher and Weaver (1991). Eight reservoirs were included in the first Rooseboom (1978) survey but many more were added in the papers published by Boucher and Weaver (1991), Rooseboom et al. (1992) and, more recently, by Baade et al. (2012) and Foster et al. (2012). The five dams surveyed by Baade et al. (2012) are especially important as all are in the Kruger National Park and probably represent yields that would approximate geologically normal rates of erosion as this area has not been subject to cultivation by European settlers. Rates in Kruger range from $\sim 10$ to $\sim 60 \mathrm{t} \mathrm{km}^{-2} \mathrm{yr}^{-1}$, averaged over 40 to 58 years from the year of construction up to the time of the field survey in 2008. The early 
estimates of reservoir sediment yield published by Rooseboom (1978) ranged from 6 to 302 $\mathrm{t} \mathrm{km}^{-2} \mathrm{yr}^{-1}$ and are in dramatic contrast to the rates published by Weaver (1989) for the Roxeni Dam, in the former Ciskei homeland, now part of the present-day Eastern Cape. Here, a reservoir survey using a hand line method to estimate locations on transects laid out across the dam at $10 \mathrm{~m}$ intervals generated a stage:volume curve that was compared with a similar curve estimated from a pre-existing topographic map. The difference in volume calculated from the two stage:volume curves was converted to sediment mass by using an assumed density of $1.35 \mathrm{t} \mathrm{m}^{-3}$ and the yield was estimated for a three-year period (1983 86) at $11,370 \mathrm{t} \mathrm{km}^{-2} \mathrm{yr}^{-1}$ for the $11.3 \mathrm{~km}^{2}$ Roxeni catchment. The Roxeni data are not included in the data base of African sediment yields compiled by Vanmaercke et al. (2014). For South Africa, the maximum reservoir-based sediment yield reported by Vanmaercke et al. (2014) was $881 \mathrm{t} \mathrm{km}^{-2} \mathrm{yr}^{-1}$ for the $\sim 1490 \mathrm{~km}^{2}$ catchment of the Xonsa dam on the White Kei river (Eastern Cape) averaged for the 12-year period between 1974 and 1985. Sediment yields for Roxeni are an order of magnitude higher than those of the Xonsa dam, although the catchment area of the former is much smaller (with a presumed higher sediment delivery ratio) and the catchment was reported by Weaver (1988) to be extremely heavily degraded. Rates were not considered to be excessively high compared with monitored rates for other degraded areas of southern Africa.

Where the former topography of a sedimentary basin is not known, or where earlier bathymetric surveys are not available, estimates of the location of the former land surface and the total volume of sediment stored in the reservoir can be made using conventional land-based coring methods during periods of drawdown. Alternative methods, such as those based on a range of volume functions for different basin shapes, were discussed by Foster et al. (2008) and showed for two dams that volume estimates could range from $\sim 43,000$ to 
$\sim 22,000 \mathrm{t}$ (average $\sim 32,000 \mathrm{t}$ ) at the first site to $\sim 37,000$ to $\sim 18,000 \mathrm{t}$ (average $\sim 28,000 \mathrm{t}$ ) at the second. Using volume functions rather than field surveys is therefore likely to increase the uncertainty in the sediment mass estimate and in the reconstructed sediment yields.

In addition to the Roxeni data, the Vanmaercke et al. (2014) data base also did not include data for the Ganora catchment for which sediment yields were published by Rowntree and Foster (2012) and summarised in Foster et al. (2012). Some 7 km NE of the town of Nieu Bethesda (lying mid way between Graaff-Reinet and Middelberg; Figure 13.1) in the Eastern Cape, the Ganora farm dam had a reconstructed sediment yield between 1970 and 2006 of $\sim 1,100 \mathrm{t} \mathrm{km}^{-2} \mathrm{yr}^{-1}$ for the $\sim 2.6 \mathrm{~km}^{2}$ catchment. While higher than all of the reservoir-based sediment yields included in the Vanmaercke et al. (2014) data base, the catchment is unusual in that almost $15 \%$ of its area is defined as badland (sensu Boardman et al., 2015) in which local erosion rates of 5.8, 4.7 and $9.1 \mathrm{~mm}$ per year from crests, midslopes and channels respectively were monitored using erosion pins (Rowntree and Foster, 2012). Sediment yields were high as a consequence of a river avulsion tapping directly into sediment delivered from a badland area, suggesting that catchment connectivity was important in delivering, or delaying, the transfer of sediment from hillslope subsystems to the local river and the Ganora dam (Rowntree and Foster, 2012).

Sediment yields estimated from reservoir surveys are difficult to compare directly with each other and with rates derived from other measurement techniques for several reasons, including the wide range of catchment areas (and sediment delivery ratios) for which estimates are made, the variable number of years over which the estimates are averaged and the fact that reservoir surveys estimate both bedload and suspended sediment load transport whereas most river surveys do not measure bedload (Vanmaercke et al., 2014). Furthermore, no major national reservoir surveys have been reported since 
those data published by Rooseboom et al. (1992) which means any increase or decrease in sediment yields in the last $\sim 2.5$ decades remain unmeasured and we have little good quality data with which to validate more recent modelled estimates of erosion rates (also see section above on river-based estimates of yield). One-off measurements of sediment yield also hide significant temporal variability, especially ramped changes in sediment yield that are driven by either sustained land use and / or climate change or a change in catchment connectivity (see Foster et al., 2012).

Historical reconstructions of sediment yield using dated sedimentary sequences in small lakes, dams and reservoirs have a long history in many parts of the world (see reviews by Foster, 2006; 2010; Walling and Foster, 2016) dating back to the classic paper of Oldfield (1977) but the approach was first evaluated in South Africa by Foster et al. (2005) and in more detail by Foster et al. (2007). It is perhaps surprising that, despite early research showing the potential for using fallout radionuclides in southern Africa in the 1990s (e.g. Stromquist, 1991; Owens and Walling, 1996), it was more than a decade before the technique was used for dating dam sediment sequences in this part of the world. The method of reconstruction requires that the sediment stack can be dated with a reasonable degree of accuracy and precision and that these dates can be transferred to other sequences in the reservoir using one of a number of easily measured parameters, such as environmental magnetic susceptibility and remanence signatures, because dating every sediment core would be prohibitively expensive. The details of how the combination of unsupported ${ }^{210} \mathrm{~Pb}_{\text {un }}$ and ${ }^{137} \mathrm{Cs}$ can be used to date sedimentary sequences are beyond the scope of this review and readers are referred to many other sources of information that describe these methodologies in detail (e.g. Walling and Foster, 2016). Both radionuclides can be measured in sediments using gamma spectrometry and, in most cases because 
sedimentation rates have not remained constant through time, the 'crs' or 'c-crs' ${ }^{210} \mathrm{~Pb}$ dating model of Appleby (2001; see Walling and Foster, 2016) is used to estimate the relationship between depth and age; confirmed wherever possible by the known age of the reservoir, the ${ }^{137} \mathrm{Cs}$ fallout history and the presence of coarse sedimentary deposits that can be dated to documented extreme daily rainfall events (see Foster et al., 2007). The four reconstructed sediment yields reported by Foster et al. (2012) all have different temporal trends, suggesting that changing regional weather and climate conditions are unlikely to be sole drivers of sustained high sediment yields but that other factors, such as cultivation history, changing rangeland management practices and changes in catchment connectivity, have driven changes in reconstructed sediment yield through time.

At scales greater than that of experimental plots, the contrast in erosion rates becomes very much a function of catchment area. Boardman et al. (2017) attempt to summarise this situation for the Sneeuberg upland in the Eastern Karoo:

Rates of erosion and sedimentation vary predictably with scales of measurement, typically $\sim 8500 \mathrm{t} \mathrm{km}^{-2} \mathrm{yr}^{-1}$ on badlands, and $\sim 500 \mathrm{t} \mathrm{km}^{-2} \mathrm{yr}^{-1}$ in small catchments. In contrast, the nearest large water-supply reservoir of Nqweba at Graaff-Reinet, has sedimentation rates of $\sim 200 \mathrm{t} \mathrm{km}^{-2} \mathrm{yr}^{-1}$ from a catchment of $2197 \mathrm{~km}^{2}$ (Msadala et al., 2011; Boardman and Foster, 2011)

$<$ MTFO>An example of the chronology derived for the Ganora catchment, and the sediment yield history of this catchment, is given in Figure 13.4. Pre-disturbance (early twentieth century) yields for Ganora and three other catchments reported in this study range from 2 to $\sim 10 \mathrm{t} \mathrm{km}^{-2} \mathrm{yr}^{-1}$ and are of a similar order of magnitude to the low rates reported by Baade et al. (2012) for the Kruger National Park. In Europe, it has been suggested that these background rates reconstructed using dated sedimentary sequences could be used as a 
guide to 'undisturbed' reference conditions for sediment transport to comply with the European Water Framework Directive (see Foster et al., 2011 and Foster and Greenwood, 2016) and could also be used to establish targets for sediment yield reduction through catchment rehabilitation in southern Africa.

\section{Figure 13.4 around here}

More recently, Foster et al. (2017) have suggested that the first occurrence of ${ }^{137} \mathrm{Cs}$ could be used to identify a common timeline (reference date or time zero) across a range of depositional environments including lake, reservoir, floodplain and alluvial fan environments shown schematically in Figure 13.5 providing an opportunity to reconstruct a partial sediment budget for catchments (see below) and establish the role of sediment stores in regulating connectivity between hillslopes and river channels and through the channel network over the past $\sim 6$ decades.

As noted by Foster et al. (2017: 32 - 33): 'Identifying 1958 - 1960 in lake and reservoir sediments using the fallout nuclide ${ }^{137} \mathrm{Cs}$ would allow a consistent estimate of sediment accumulation, and sediment yield, to be dated back to a common national baseline, making estimates between sites directly comparable.'

\section{Sediment budgets}

A sediment budget defines four components in terms of catchment sediment dynamics: sediment sources, transport pathways, storage areas and sediment export (as bedload and / or suspended load) at the scale of the catchment or drainage basin over a specific timescale or over a range of different timescales. Measurements of sediment export, as sediment yield, reflect the integration of all the above processes and transport pathways and, in recent years the idea of connectivity has been integrated with the idea of the sediment 
budget to conceptually strengthen our understanding of the different scales (temporal and spatial) at which budgets and connectivity operate (see Burt and Allison, 2011, and Fryirs and Gore, 2013, for a more detailed discussion). For example, at the catchment scale, hillslope-channel linkages can be made through the extension of continuous gullies from hillslopes to the channel or river, thereby providing for almost uninterrupted movement of sediment between the hillslope and channel system. Valley-bottom gullies (dongas) may connect remote parts of the channel network to the downstream system while noncontinuous gullies often end in alluvial fans or floodouts which remain largely disconnected from the channel network, thereby reducing the connectivity and increasing the opportunity for storage. At the scale of the river channel, sediment may move from transport in the channel to overbank deposits (in stores such as floodplains or flood benches) during flood events and may also be exchanged between the channel bed and river itself. Floodouts and channel avulsions may change connectivity in catchments and their channel networks (see Grenfell et al., 2014, for example, for a discussion of historical changes in connectivity in two different climatic zones in South Africa). Man-made structures, like dams and reservoirs, introduce new storage components into natural catchments that partially disconnect parts of the catchment from the downstream channel when the dam is operational but reconnect the upper catchment to the downstream channel if the dam wall is breached (see Boardman and Foster, 2011; Foster et al., 2012). A conceptual model of what a semi-arid sediment budget model for southern Africa might need to measure is shown in diagrammatic form for a small catchment in Figure 13.5. It typically shows hillslopes with discontinuous soil cover, long-term storage of sediment in colluvial fill and a range of features that now commonly occupy southern African landscapes such as badlands, dongas, valley-side gullies, alluvial fans and floodouts. 
To date, no known study has reconstructed an entire sediment budget for a southern African catchment, but many studies have made partial reconstructions and measured process rates in parts of the catchment (see earlier section on hillslope erosion rates). Storage rates and estimates of sediment export can be based on dated sediment sequences within catchments such as on floodplains, in floodouts and alluvial fans and in farm dams (export rates) which provide information on partial sediment budgets and add a second important dimension, that of allowing the properties of the deposited sediment to track sediment sources and their possible changes through time.

Many studies have dated floodplain deposits, floodouts, fans and / or flood benches using a combination of the fallout nuclides ${ }^{210} \mathrm{~Pb}$ and ${ }^{137} \mathrm{Cs}$ analysis and, occasionally, ${ }^{14} \mathrm{C}$ dating and have identified changes in these parts of the fluvial system using a range of analyses that often include measurements of particle size and organic matter content. A detailed evaluation of the dating methods is beyond the scope of this review (see Walling and Foster, 2016 and Walker, 2005). Changes in the dated sediment properties are then related to documented historical weather patterns, changing land management and / or changing connectivity (e.g. Yamagata, 2010; Manjoro et al., 2012, Foster et al., 2012; Grenfell et al., 2012; van der Waal, 2014; van der Waal et al., 2015). The study by Yamagata (2010), for example, attributed the coarsening of recent floodplain deposits in the central section of the Kuiseb River, Namibia to a change in sediment source as dams constructed in the headwaters of the river since the latter half of the twentieth century cut off the supply of fine sediment to the downstream river channel which became dominated by sand blowing in from the Namib desert. Grenfell et al. (2012) demonstrated that gullying and floodouts were common features of the central Karoo region of South Africa and that several phases of floodout development had occurred in the recent historical past. 


\section{Sediment fingerprinting}

A significant development over the past decade has been the use of sediment fingerprinting in order to determine the origins of sediment transported by rivers and deposited in a range of settings illustrated in Figure 13.5. Sediment fingerprinting has a long history outside of southern Africa and has been used in many countries to try and help managers target mitigation strategies by identifying the most likely source of sediment. The methodology is still developing and many recent reviews have attempted to identify the status of the technique and how it should be applied (e.g. Foster, 2000; Small et al., 2004; Walling, 2005; Walling and Foster, 2016; Collins et al., 2017). Given the likely cost savings by targeting mitigation strategies, the technique has enormous potential, for example, to reduce the high rates of sedimentation in southern African water supply reservoirs and farm dams.

Fingerprinting principles require that different sediment sources (e.g. based on geology, land use or source type such as river channel banks, badlands, dongas) can be differentiated on the basis of their physical, chemical or organic characteristics. Research in South Africa has tested a range of techniques, often in combination, in order to establish potential sediment sources, and identify drivers of environmental change such as land use and vegetation, including geogenic and fallout radionuclides, environmental magnetism, sediment geochemistry, colour, particle size, pollen, diatoms, charcoal and non-pollen palynomorphs (NPPs) (Meadows and Baxter, 2001; Foster et al., 2005, 2007; Neumann et al., 2011; Foster and Rowntree, 2012; Manjoro et al., 2012; Mighall et al., 2012; Rowntree and Foster, 2012; Pulley et al., 2015; van der Waal et al., 2015; Kirsten and Meadows, 2016; Pulley and Rowntree, 2016 a, b; Quick et al., 2016). Cost of analysis will often determine the chosen fingerprint / reconstruction methodology but Foster et al. $(2005,2007)$ and 
Rowntree and Foster (2012) demonstrated that measurements of simple environmental magnetic parameters could prove of significant value in determining sediment sources and Pulley et al. (2015) showed that these signatures were mostly well preserved in farm dam sediments, showing only limited post-depositional diagenesis, but that account should be taken of the particle size distribution of sources and deposited sediment, as tracer signatures were strongly controlled by particle size. Sediment colour was first used in South Africa by Pulley et al. (2016a) who demonstrated that differences between geological sources (dolerite and sandstone) using an ordinary colour scanner compared favourably with those obtained using environmental magnetism. More expensive analytical options, such as the use of geogenic and fallout radionuclides, determined using alpha- and / or gamma spectrometry and sediment geochemistry, determined by X-Ray Fluorescence or ICP-OES following digestion in a microwave digestion system (see Walling and Foster, 2016) may offer additional parameters with which to refine the fingerprint solution (e.g. Foster et al., 2007) but may not always add better discriminatory power than cheaper options. To date no known studies have attempted to fingerprint sediment sources using organic parameters in southern Africa.

Figure $\mathbf{1 3 . 5}$ around here

\section{Combining sediment yield reconstruction and sediment source fingerprinting}

In combination, dating, sediment yield reconstruction and fingerprinting based on dam sediments offer an opportunity to quantify changes in sediment yield through time and identify the most likely sediment sources which would allow catchment managers to target potential mitigation strategies. For example, Foster et al. (2012) report a study undertaken at Cranemere on the Plains of Camdeboo in the Eastern Cape to reconstruct sediment yield 
and determine historical changes in sediment sources since construction of a dam in the mid-nineteenth century. Here, sediment yields were shown to increase dramatically after $\sim 1950$, reaching a maximum of $\sim 250 \mathrm{t} \mathrm{km}^{-2} \mathrm{yr}^{-1}$, probably as a result of reconnecting the upper eastern and western tributary catchments by raising the level of the R63 onto a causeway and building culverts beneath it to carry water from the two tributary streams to Cranemere dam. However, two periods in the past (dated to the early 1940s and mid 1970s respectively) were associated with a major reduction in magnetic susceptibility in the sediments of Cranemere dam, which appeared to derive mostly from the smaller eastern catchment where potential sources generally had lower magnetic susceptibilities than those of the much larger western stream (Figure 13.6). This conclusion was confirmed by analysis of a floodout deposit in the western catchment just upstream of the R63 that dated back to the early 1940s and had continued to accumulate sediment since that time. The analysis showed no reduction in magnetic susceptibility that could match the trends observed in Cranemere dam sediments, confirming that the western stream was most unlikely to be the dominant source of sediment deposited in the dam during major flood events (known to have occurred in the rainfall records from 1941 and 1974).

\section{Figure 13.6 around here}

While further refinements in fingerprinting methods remain to be made (see Collins et al., 2017), there is little doubt that fingerprinting offers a major opportunity to focus limited resources on those areas of catchments that dominate sediment supply, thereby reducing the potential threat posed by high rates of reservoir sedimentation.

\section{Socio-political issues}


In our need to address the new approaches to monitoring and assessment of land degradation we are in danger of forgetting that erosion is driven primarily by socioeconomic and political forces (Boardman et al., 2003). Southern Africa is rife with examples. We have already mentioned Talbot's (1947) analysis of Swartland erosion. Hoffman and Ashwell (2001) point to the contrasts between degradation in the over-populated and resource-poor areas of the former 'homelands', such as the Transkei and the Ciskei (Eastern Cape), and the white-owned commercial farming areas. The devastation caused by so-called Betterment Planning is eloquently seen in pictures of the Herschel area (Eastern Cape) in Hoffman and Ashwell (2001) and reproduced in Boardman et al. (2012). To a large extent, monitoring and assessment of land degradation is an exercise in recording the results and impacts of unwise land use practices in the past, some of which continue into the present.

\section{Conclusion}

While the causes of land degradation are complex, and frequently involve socio-political drivers as well as specific land management methods, there is ample evidence reviewed in this chapter to suggest that land degradation is a real issue in southern Africa. There is substantive evidence to support this contention relating to recent historical increases in erosion rates that show few signs of a major reduction in recent decades. It is also evident that many of the data bases and models of hillslope and catchment erosion do not provide catchment managers with appropriate information or suitable tools to manage the problem effectively. However, this chapter has also reviewed several approaches for assessing rates of erosion that could be used to effectively target mitigation. Such targeting is essential in countries that need to spend significant sums of money on erosion control and require best value for money. However, failure to act in the short term is likely to lead to significant long- 
term problems as southern African water security is under severe pressures that will increase in the near future (years to decades) as a result of reservoir sedimentation. Most southern African economies are dependent on a reliable and sustainable water supply that can only be assured for the long-term future by judicious spending on reducing the extent of land degradation and more effectively targeting erosion control strategies. A range of monitoring and assessment strategies are available and have often been tested or developed in southern Africa. Low cost strategies are plentiful and have been shown to work well in providing quantitative estimates of erosion and land degradation. The increasing global reliance on numerical modelling, as opposed to measurement, in many environmental settings is of growing concern as untested models potentially lead to incorrect estimates of erosion and degradation and can lead to the introduction of inappropriate and expensive mitigations.

\section{References}

Appleby P G, 2001. Chronostratigraphic techniques in recent sediments. In Last WM and Smol JP (eds) Tracking Environmental Change Using Lake Sediments. Volume 1; Basin Analysis, Coring and Chronological Techniques. Dordrecht, Kluwer: 171-204.

Baade J, Franz S, Reichel A. 2012. Reservoir siltation and sediment yield in the Kruger National Park South Africa. Land Degradation \& Development 23(6): 586 - 600.

Bannatyne L J, Rowntree K M, van der Waal B W, Nyamela N. 2017. Design and implementation of a citizen technician-based suspended sediment monitoring network: Lessons from the Tsitsa River catchment, South Africa. Water SA 43(3): 365 377. 
Beugler-Bell H, Buch M W. 1997. Soils and soil erosion in the Etosha National Park, northern Namibia. MADOQUA, 20: 91 - 104.

Boardman J. 2006. Soil erosion science: Reflections on the limitations of current approaches. Catena 68(2/3): $73-86$.

Boardman J. 2014. How old are the gullies (dongas) of the Sneeuberg uplands, eastern Karoo, South Africa? Catena 113: 79 - 85.

Boardman J, Favis-Mortlock D. 2016. The use of erosion pins in geomorphology. In Geomorphological Techniques (Online Edition), Cook S J, Clarke L E, Nield J M (eds). British Society for Geomorphology: London, UK; Chap. 3, Sec. 5.1.

Boardman J, Favis-Mortlock D T, Foster I D L. 2015. A 13-year record of erosion on badland sites in the Karoo, South Africa. Earth Surface Processes and Landforms 40: 1964 1981.

Boardman J, Foster I D L. 2011. The potential significance of the breaching of small farm dams in the Sneeuberg region, South Africa. Journal of Soils and Sediments 11: 1456 1465.

Boardman J, Foster I D L, Rowntree K, Favis-Mortlock D, Suich H, Gaynor D. 2017. Long-term studies of land degradation in the Sneeuberg uplands, eastern Karoo, South Africa: A synthesis. Geomorphology 285: 106 - 120.

Boardman J, Hoffman T, Holmes P, Wiggs G. 2012. Soil erosion and land degradation. In Southern African Geomorphology: Recent Trends and New Directions, Holmes P, Meadows M. (eds). Sun Press: Bloemfontein; 307 - 328.

Boardman J, Poesen J, Evans R. 2003. Socio-economic factors in soil erosion and conservation. Environmental Science and Policy 6(1): 1 - 6. 
Boucher K, Weaver A van B. 1991. Sediment yield in South Africa: A preliminary analysis. GeoJournal 23(1): 7 - 17.

Burt T, Allison R J. (eds). 2011. Sediment Cascades. Wiley: Chichester, UK.

Chakela Q K. 1981. Soil Erosion and Reservoir Sedimentation in Lesotho. Scandinavian Institute of African Studies, Uppsala, UNGI Rapport Nr 54, Department of Physical Geography, University of Uppsala.

Chakela Q K, Stocking M. 1988. An improved methodology for erosion hazard mapping. Part II. Application to Lesotho. Geografiska Annaler 70A: 181 - 189.

Collins A L, Pulley S, Foster I D L, Gellis, A, Porto P, Horowitz A J. 2017. Sediment source fingerprinting for informing catchment management: Methodological approaches, problems and uncertainty - a review of the current state of knowledge. Journal of Environmental Management 194: 86 - 108.

Compton J S, Herbert C T, Hoffman M T, Schneider R R, Stuut J-B. 2010. A tenfold increase in the Orange River mean Holocene mud flux: Implications for soil erosion in South Africa. The Holocene 20: 115 - 122.

Dedkov A P, Mozzherin V I. 1984. Erosia i stok nanosov mi zemle (Erosion and Sediment Yield on the Earth). Izdatelstvo Kazanskogo Universiteta: Kazan, Russia, 264 pp (cited by Vanmaercke, 2014).

Evans R, Boardman J. 2016. The new assessment of soil loss by water erosion in Europe. Panagos P. et al. 2015 Environmental Science \& Policy 54, 438 - 447 - A response. Environmental Science \& Policy 58: 11 - 15.

European Soil Data Centre (ESDAC). n.d. Erosion Hazard Maps. Available from: https://esdac.jrc.ec.europa.eu/search/node/erosion hazard (accessed 13 March 2018). 
FAO. 2008. AQUASTAT global river sediment yields database. Available from:

www.fao.org/nr/water/aquastat/sediment/index.stm (accessed 13 March 2018).

Felix-Henningsen P, Morgan R P C, Mushala H M, Rickson R J, Scholten T. 1997. Soil erosion in Swaziland: A synthesis. Soil Technology 11: 319 - 329.

Foster, I D L (ed). 2000. Tracers in Geomorphology. Wiley: Chichester, UK.

Foster I D L. 2006. Lakes in the sediment delivery system. In Soil Erosion and Sediment Redistribution in River Catchments, Owens P N, Collins, A J (eds). Wallingford: CAB International; 128 - 142.

Foster I D L. 2010. Lakes and reservoirs in the sediment cascade. In Sediment Cascades: An Integrated Approach, Burt T P, Allison R J (eds). Chichester: Wiley; 345 - 376.

Foster I D L, Boardman J, Collins A L, Copeland-Phillips R, Kuhn N J, Mighall T M, Pulley S, Rowntree K M. 2017. The potential for gamma-emitting radionuclides to contribute to an understanding of erosion processes in South Africa (Proc. ICCE Conference, Okehampton. July 2016). IAHS PubI. 375: 29 - 34.

Foster I D L, Boardman J, Gates J. 2008. Reconstructing historical sediment yields from the infilling of farm reservoirs, Eastern Cape, South Africa. In Sediment Dynamics in Changing Environments (Proceedings of a symposium held in Christchurch, New Zealand, December 2008). IAHS Publ. 325: 139 - 142.

Foster, I D L, Boardman J, Keay-Bright J. 2007. The contribution of sediment tracing to an investigation of the environmental history of two small catchments in the uplands of the Karoo, South Africa. Geomorphology 90(1 - 2): 126 - 143.

Foster I D L, Boardman J, Keay-Bright J, Meadows M E. 2005. Land degradation and sediment dynamics in the South African Karoo. In Sediment Budgets, Walling D E, Horowitz A (eds). (Proceedings IAHS, Foz do Iguacu), IAHS Publ. 295: 207 - 213. 
Foster I D L, Collins A L, Naden P S, Sear D A, Jones J I, Zhang Y. 2011. The potential for paleolimnology to determine historic sediment delivery to rivers. Journal of Paleolimnology 45(2): 287 - 306.

Foster I D L, Greenwood M T. 2016. Linking the past to the present: The use of palaeoenvironmental data for establishing reference conditions for the Water Framework Directive. In River Systems: Research and Management for the $21^{\text {st }}$ Century, Gilvear D J, Greenwood M T, Thoms M C, Wood P J. (eds). Wiley: Chichester, UK; $61-83$.

Foster I D L, Rowntree K M. 2012. Historic land management, rainfall and sediment yield changes in the semi-arid Karoo: A palaeoenvironmental reconstruction and interpretation of sediments accumulating in Cranemere Reservoir, Eastern Cape, South Africa. Zeitschrift für Geomorphologie 56 (Suppl 3): 131 - 146.

Foster I D L, Rowntree K, Boardman J, Mighall T. 2012. Changing sediment yield and sediment dynamics in the Karoo uplands, South Africa: Post-European impacts. Land Degradation \& Development 23: 508 - 522.

Fryirs K A, Gore D B. 2013. Sediment tracing in the upper Hunter catchment using elemental and mineralogical compositions: Implications for catchment-scale suspended sediment (dis)connectivity and management. Geomorphology 193: 112 - 121.

Garland G G, Hoffman M T, Todd S. 2000. Chapter 6: Soil degradation. In A National Review of Land Degradation, Hoffman M T, Todd S, Ntshona Z, Turner S. (eds). South African National Biodiversity Institute: Pretoria; 69 - 107.

Grenfell S E, Ellery W N. 2009. Hydrology, sediment transport dynamics and geomorphology of a variable flow river: The Mfolozi River, South Africa. Water SA 35: 271 - 282. 
Grenfell S E, Grenfell M C, Rowntree K M, Ellery W N. 2014. Fluvial connectivity and climate: A comparison of channel pattern and process in two climatically contrasting fluvial sedimentary systems in South Africa. Geomorphology 205: 142 - 154.

Grenfell S E, Rowntree K M, Grenfell M C. 2012. Morphodynamics of a gully and floodout system in the Sneeuberg Mountains of the semi-arid Karoo, South Africa: Implications for local landscape connectivity. Catena 89: 8 - 21.

Hoffman M T, Ashwell A. 2001. Nature Divided: Land Degradation in South Africa. UCT Press: Cape Town.

Kakembo V. 2001. Trends in vegetation degradation in relation to land tenure, rainfall, and population changes in Peddie District, Eastern Cape, South Africa. Environmental Management 28(1): 39 - 46.

Kakembo V, Rowntree K M. 2003. The relationship between land use and soil erosion in the communal lands near Peddie Town, Eastern Cape, South Africa. Land Degradation \& Devlopment 14: 39 - 49.

Keay-Bright J, Boardman J. 2006. Changes in the distribution of degraded land over time in the central Karoo, South Africa. Catena 67: 1 - 14.

Kirsten K L, Meadows M E. 2016. Late-Holocene palaeolimnological and climate dynamics at Princessvlei, South Africa: Evidence from diatoms. The Holocene doi:

\section{$10.1177 / 0959683616640049$}

Klintenberg P, Seeley M. 2004. Land degradation monitoring in Namibia: A first approximation. Environmental Monitoring and Assessment 99: 5 - 21.

Laker M C. 2004. Advances in soil erosion, soil conservation, land suitability, evaluation and land use planning research in South Africa, 1978 - 2003. South African Journal Plant Soil 21(5): 345 - 368. 
Le Roux J J, Newby T S, Sumner P D. 2007. Monitoring soil erosion in South Africa at a regional scale: Review and recommendations. South African Journal of Science 103: $329-335$.

Manjoro M, Kakembo V, Rowntree K M, Foster I D L. 2012. Gully fan morphodynamics in a small catchment in the Eastern Cape, South Africa. Land Degradation \& Development 23(6): $569-576$.

Mararakanye N, Le Roux J J. 2012. Gully location mapping at a national scale for South Africa. South African Geographical Journal 94(2): 208 - 218.

Meadows M E. 2003. Soil erosion in the Swartland, Western Cape Province, South Africa: Implications of past and present policy and practice. Environmental Science \& Policy 6: $17-28$.

Meadows M E, Baxter A J. 2001. Holocene vegetation history and palaeoenvironments at Klaarfontein Springs, Western Cape, South Africa. The Holocene 11(6): 699 - 706. Meadows M E, Hoffman M T. 2002. The nature, extent and causes of land degradation in South Africa: Legacy of the past, lessons for the future? Area 34: 428 - 437. Mighall T M, Foster I D L, Rowntree K M, Boardman J. 2012. Reconstructing recent land degradation in the Semi-Arid Karoo of South Africa: A palaeoecological study at Compassberg, Eastern Cape. Land Degradation \& Development 23(6): 523 - 533.

Milliman J D, Farnsworth K L. 2011. River Discharge to the Coastal Ocean: A Global Synthesis. Cambridge University Press: Cambridge, UK.

Morgan R P C, Rickson R J, Mclntyre K, Brewer T R, Altshul H J. 1997. Soil erosion survey of the central part of the Swaziland Middleveld. Soil Technology 11: 263 - 269.

Morgan R P C, Mngomezulu D. 2003. Threshold conditions for initiation of valley-side gullies in the Middle Veld of Swaziland. Catena 50: 401 - 411. 
Msadala V, Gibson L, Le Roux J J, Rooseboom A, Basson G R. 2011. Sediment Yield Prediction for South Africa: 2010 Edition, Water Research Commission Report No. 1765/1/10, 250 pp.

Mushala H M. 1988. Soil erosion in Swaziland: A review of research needs. Swaziland Journal of Science and Technology 9: 7 - 19.

Mushala H M. 1997. Soil erosion and indigenous land management: Some socio-economic considerations. Soil Technology 11: 301 - 310.

Mushala H M, Morgan R P C, Scholten T, Felix-Henningsen P, Rickson R J. 1997. Soil erosion and sedimentation in Swaziland: An introduction. Soil Technology 11: 219 - 228.

Neumann F H, Scott L, Bamford M K. 2011. Climate change and human disturbance of fynbos vegetation during the late Holocene at Princess Vlei, Western Cape, South Africa. The Holocene 21(7): 1137 - 1149.

Oldeman L R, Hakkeling R T A, Sombroek W G. 1991. World map of the status of humaninduced soil degradation: An explanatory note. International Soil Reference and Information Centre: Wageningen; United Nations Environment Programme: Nairobi.

Oldfield F. 1977. Lakes and their drainage basins as units of sediment-based ecological study. Progress in Physical Geography 1: 460 - 504.

Owens P N, Walling D E. 1996. Spatial variability of Caesium-137 Inventories at reference sites: An example from two contrasting sites in England and Zimbabwe. Appl Radiat. Isot. 47(7): 699 - 707.

Pulley S, Rowntree K M. 2016a. The use of an ordinary colour scanner to fingerprint sediment sources in the South African Karoo. Journal of Environmental Management 165: $253-262$. 
Pulley S, Rowntree K M. 2016b. Stages in the life of a magnetic grain: Sediment source discrimination, particle size effects and spatial variability in the South African Karoo. Geoderma 271: 134 - 143

Pulley S, Rowntree K M, Foster I D L. 2015. Conservation of Mineral Magnetic Signatures in farm dams sediments in the South African Karoo: The potential effects of particle size and post-depositional diagenesis. Journal of Soils and Sediments 15: 2387 - 2397.

Quick L J, Meadows M E, Bateman M D, Kirsten K L, Mäusbacher R, Haberzettl T, Chase B M. 2016. Vegetation and climate dynamics during the last glacial period in the fynbos afrotemperate forest ecotone, southern Cape, South Africa. Quaternary International 404: $136-149$.

Reed M S, Fazey I, Stringer L C, Raymond C M, Akhtar-Schuster M, Begni G, Bigas H, Brehm S, Briggs J, Bryce R, Buckmaster S, Chanda R, Davies J, Diez E, Essahli W, Evely A, Geeson N, Hartmann I, Holden J, Hubacek K, Ioris A A R, Kruger B, Laureano P, Phillipson J, Prell C, Quinn C H, Reeves A D, Seeley M, Thomas R, Van der Werff Ten Bosch M J, Vergunst P, Wagner L. 2013. Knowledge management for land degradation monitoring and assessment: An analysis of contemporary thinking. Land Degradation and Development 24: 307 - 322.

Rooseboom A. 1978. Sedimentafvoer in Suide-Afrikaanse riviere [Sediment transport in Southern African rivers]. Water SA 4: 14 - 17 (in Afrikaans; cited by Vanmaerck, 2014). Rooseboom A, Verster E, Zietsman H L, Lotriet H H. 1992. The development of the new sediment yield map of South Africa. WRC Report No. 297/2/92. Water Research Commission: Pretoria, South Africa. 
Rowntree K M. 2012. Fluvial Geomorphology. In Southern African Geomorphology: Recent trends and new directions, Holmes P, M Meadows M (eds). Sun Press: Bloemfontein; $97-140$.

Rowntree K M. 2013. The evil of 'sluits'. Journal of Environmental Management 130: 98 105.

Rowntree K M, Foster I D L. 2012. A reconstruction of historical changes in sediment sources, sediment transfer and sediment yield in a small semiarid Karoo catchment, South Africa. Zeitschrift für Geomorphologie 56(1): 87 - 100.

Rowntree K M, Duma M, Kakembo V, Thornes J B. 2004. Debunking the myth of overgrazing and soil erosion. Land Degradation and Development 15: 203 - 214.

Russow F, Garland G. 2000. Factors accounting for the rapid siltation of Hazelmere Dam, KwaZulu-Natal. South African Geographical Journal 82(3): 182 - 188.

Scott D F, Versfeld D B, Lesch W. 1998. Erosion and sediment yield in relation to afforestation and fire in the mountains of the Western Cape Province, South Africa. South African Geographical Journal 80: 52 - 59.

Showers K B. 1989. Soil erosion in the Kingdom of Lesotho: Origins and colonial response, 1830s to 1950s. Journal of Southern African Studies 15: 263 - 286.

Showers K B. 1996. Soil erosion in the kingdom of Lesotho and development of historical environmental impact assessment. Ecological Applications 6(2): 653 - 664.

Showers K B. 2005. Imperial Gullies: Soil Erosion and Conservation in Lesotho. Ohio University Press: Athens, Ohio.

Small I F, Rowan J S, Franks S W, Wyatt A, Duck R W. 2004. Bayesian sediment fingerprinting provides a robust tool for environmental forensic geoscience application. In Forensic 
Geoscience: Principles, Techniques and Applications 232. Geological Society, London, Special Publications; 207 - 213.

Smith H J, 1999. Application of empirical soil loss models in southern Africa: a review. South African Journal of Plant and Soil 16(3); 158-163.

Stringer L C, Reed M S. 2007. Land degradation assessment in southern Africa: Integrating local and scientific knowledge bases. Land Degradation and Development 18: 99 - 116.

Strohbach B J. 2002. Soil erosion: Causative factors, extent and prevention. Agri-Info 6(1): 8 14.

Stromquist L. (ed). 1991. Monitoring soil loss at different observation levels: Case studies of soil erosion in the Lesotho lowlands. Uppsala University, Department of Physical Geography UNGI, Rapport Nr 74.

Talbot W J. 1947. Swartland and Sandveld. Oxford University Press: Cape Town.

Thomas D S G, Sporton D, Perkins J. 2000. The environmental impact of livestock ranches in the Kalahari, Botswana: Natural resource use, ecological change and human response in a dynamic dryland system. Land Degradation and Development 11: 327 - 341.

Tooth S, McCarthy T S. 2007. Wetlands in drylands: Geomorphological and sedimentological characteristics, with emphasis on examples from southern Africa. Progress in Physical Geography 31(1): 3 - 41.

Van der Waal B W. 2014. Sediment Connectivity in the Upper Thina Catchment, Eastern Cape, South Africa. PhD thesis, Rhodes University.

Van de Waal, B W, Rowntree K M, Pulley S. 2015. Flood bench chronology and sediment source tracing in the upper Thina catchment, South Africa: The role of transformed landscape connectivity. Journal Soils and Sediments 15: 2398 - 2411. 
Vanmaercke M, Poesen J, Broeckx J, Nyssen J. 2014. Sediment yield in Africa. Earth-Science Reviews 136: 350 - 368.

Walker M. 2005. Quaternary Dating Methods. Chichester: Wiley.

Walling D E. 2005. Tracing suspended sediment sources in catchments and river systems. Science of the Total Environment 344: 159 - 184.

Walling D E, Foster, I D L. 2016. Using environmental radionuclides and sediment geochemistry for tracing and dating fine fluvial sediment. In Tools in Fluvial Geomorphology, Kondolf M, Piegay H (eds). Chichester: Wiley; $2^{\text {nd }}$ ed., 183 - 209.

Walling D E, Webb B W. 1983. Patterns of sediment yield. In Background to Palaeohydrology, Gregory K J (ed.). Wiley: Chichester, UK; 69 - 100.

Weaver A van B. 1989. Soil erosion rates in the Roxeni Basin, Ciskei. South African Geographical Journal 71(1): 32-37.

WMS Associates. 1988. Gully erosion in Swaziland. Final Report. International Development Research Centre, Ottawa, Canada.

Yamagata K. 2010. Recent grain-size coarsening of floodplain deposits and forest decline along the Kuiseb River, Namib Desert, Namibia. African Study Monographs, Suppl. 40: $19-30$. 

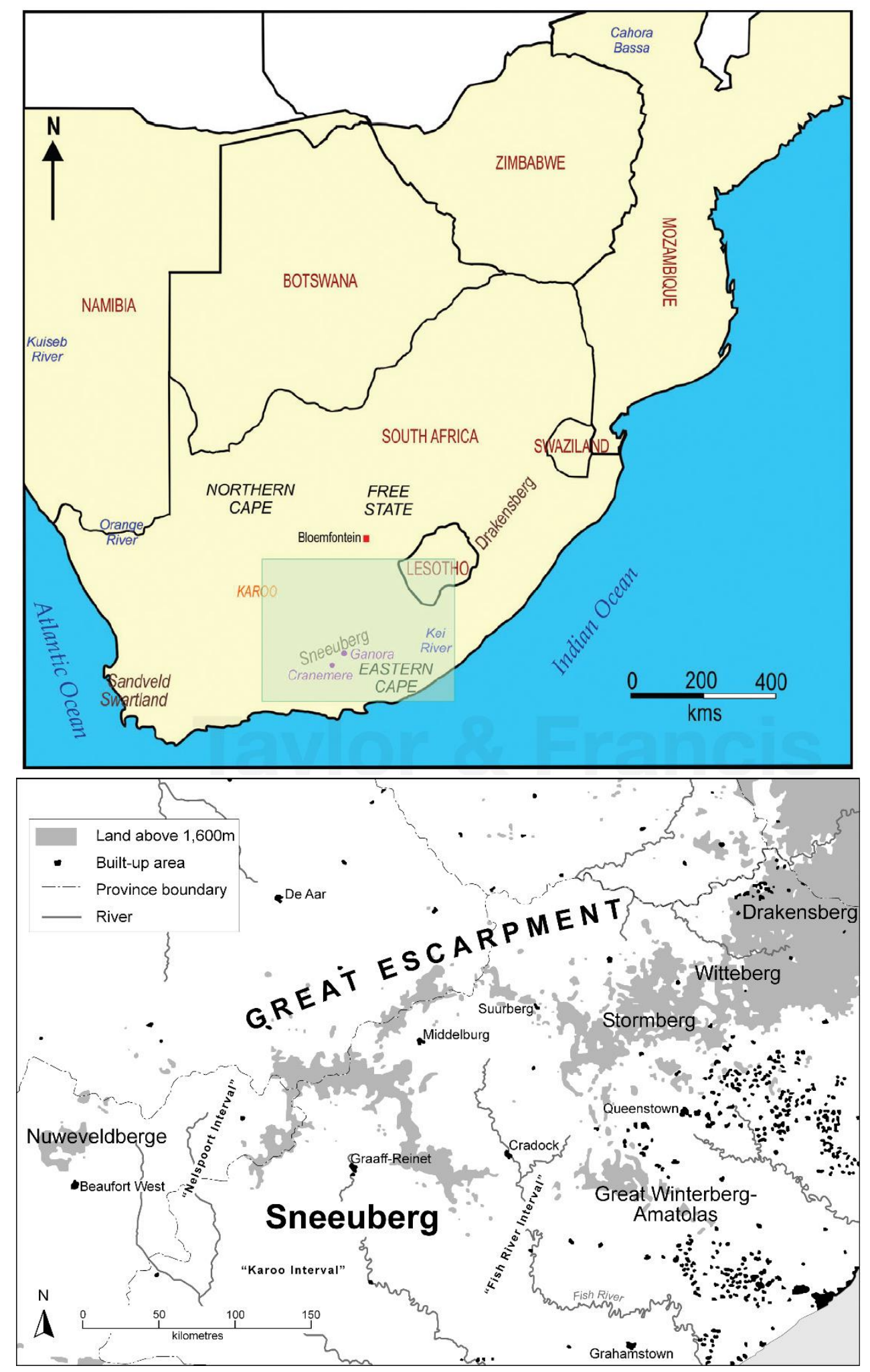

Figure 13.1 (a) The situation of the Sneeuberg area and some other place names mentioned in this chapter; (b) The Sneeuberg area 


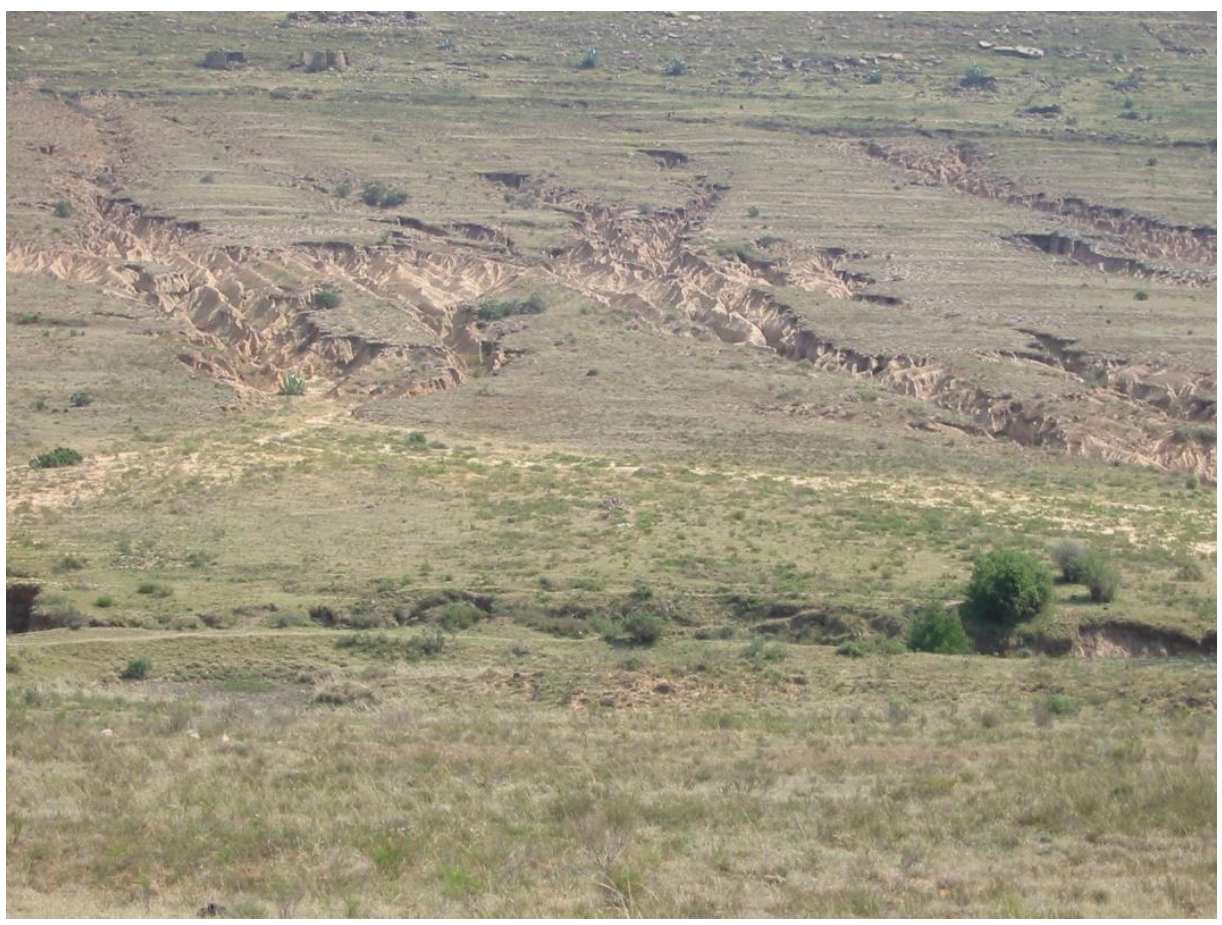

b

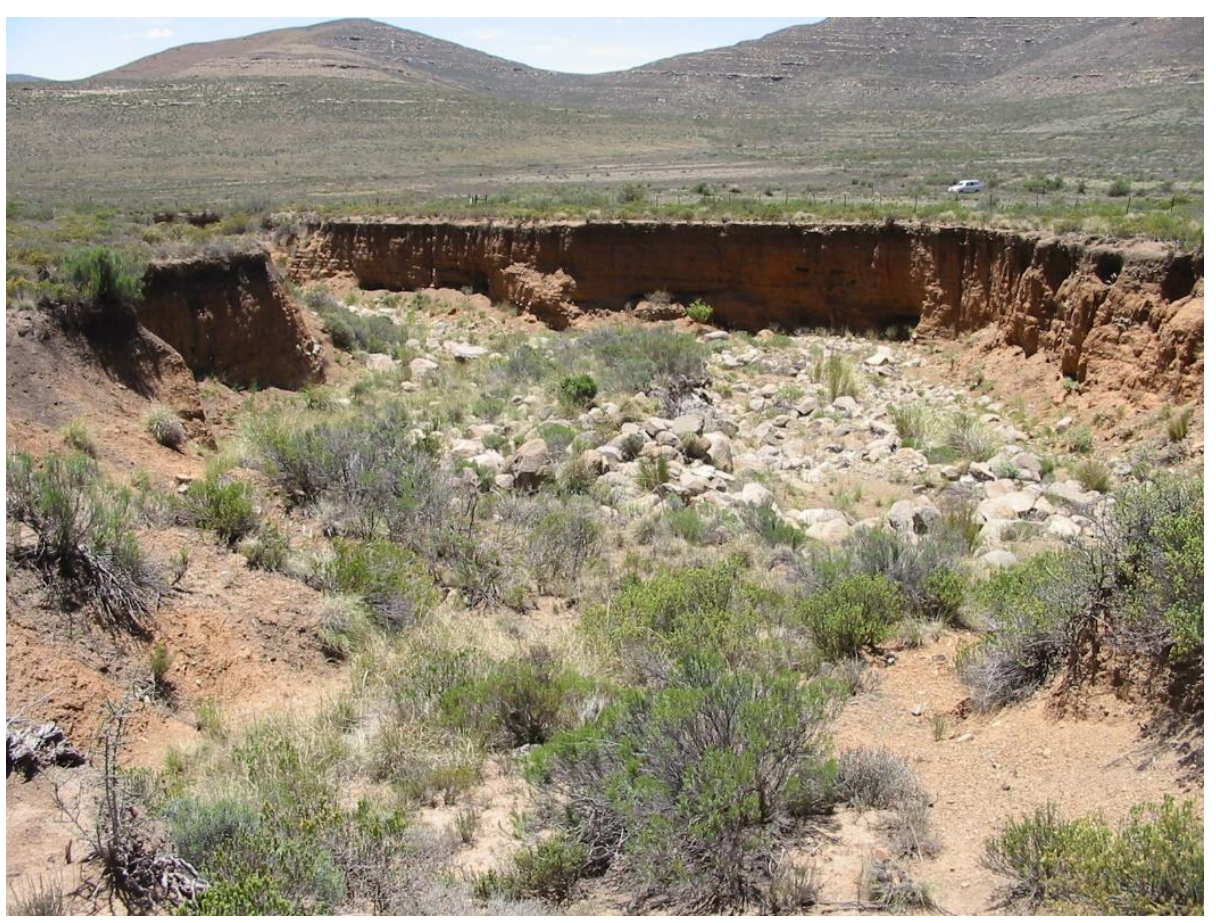

Figure 13.2 (a) Badland in the Sneeuberg; (b) Gully in the Sneeuberg 


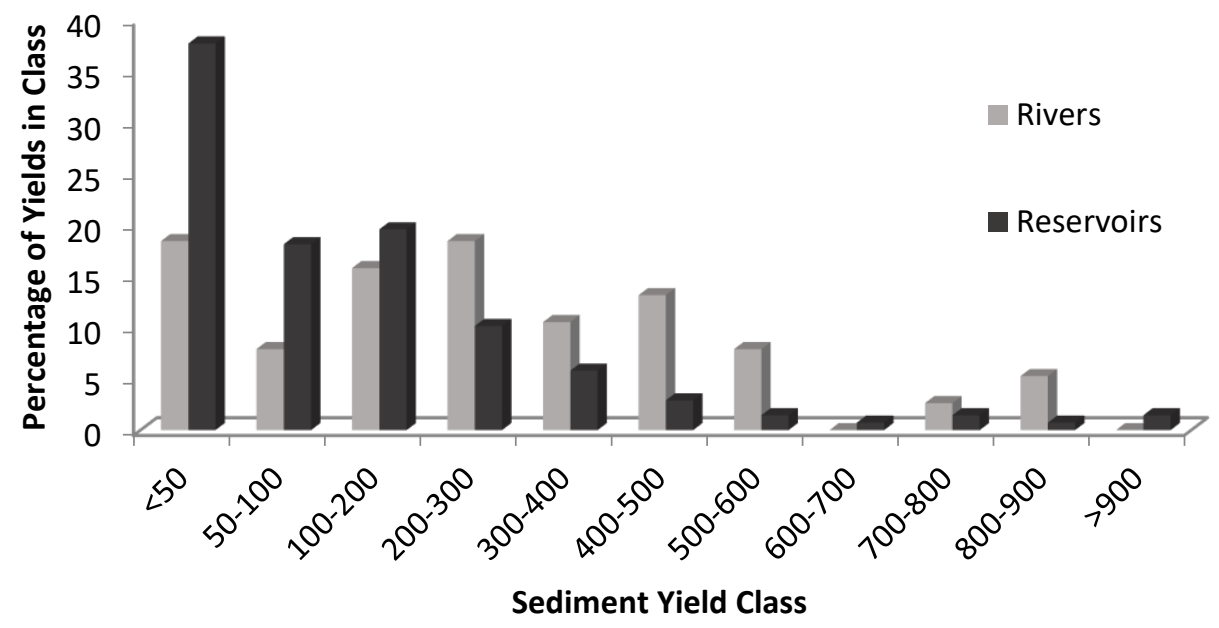

Figure 13.3 Comparison of the frequency distribution of South African sediment yields in the Vanmaercke et al. (2014) data base supplemented by the Roxeni and Ganora data (see text for explanation).

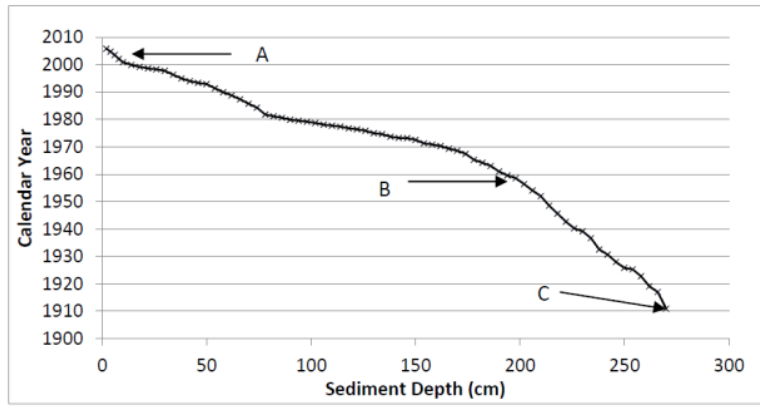

A

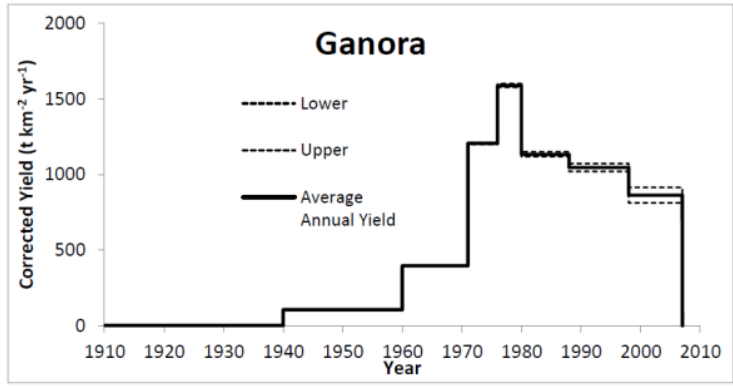

B

Figure 13.4a The Ganora Reservoir: depth:age curve based on the Appleby (2001) ${ }^{210} \mathrm{~Pb}$ 'c-ccrs' dating model. Labels: $\mathbf{a}=$ Coring Date (August 2006); $\mathbf{b}={ }^{137} \mathrm{Cs}$ first occurrence in South African deposits (1958; see Foster et al., 2012); c = known date of reservoir commissioning (1910) (Hester and J.P. Steynberg, Ganora Farm. Pers. comm. 2006)

Figure 13.4b The Ganora Reservoir: sediment yield reconstruction; upper, lower and average sediment yields based on the range of Trap Efficiency estimates calculated by the methods of Foster et al. (2008) 


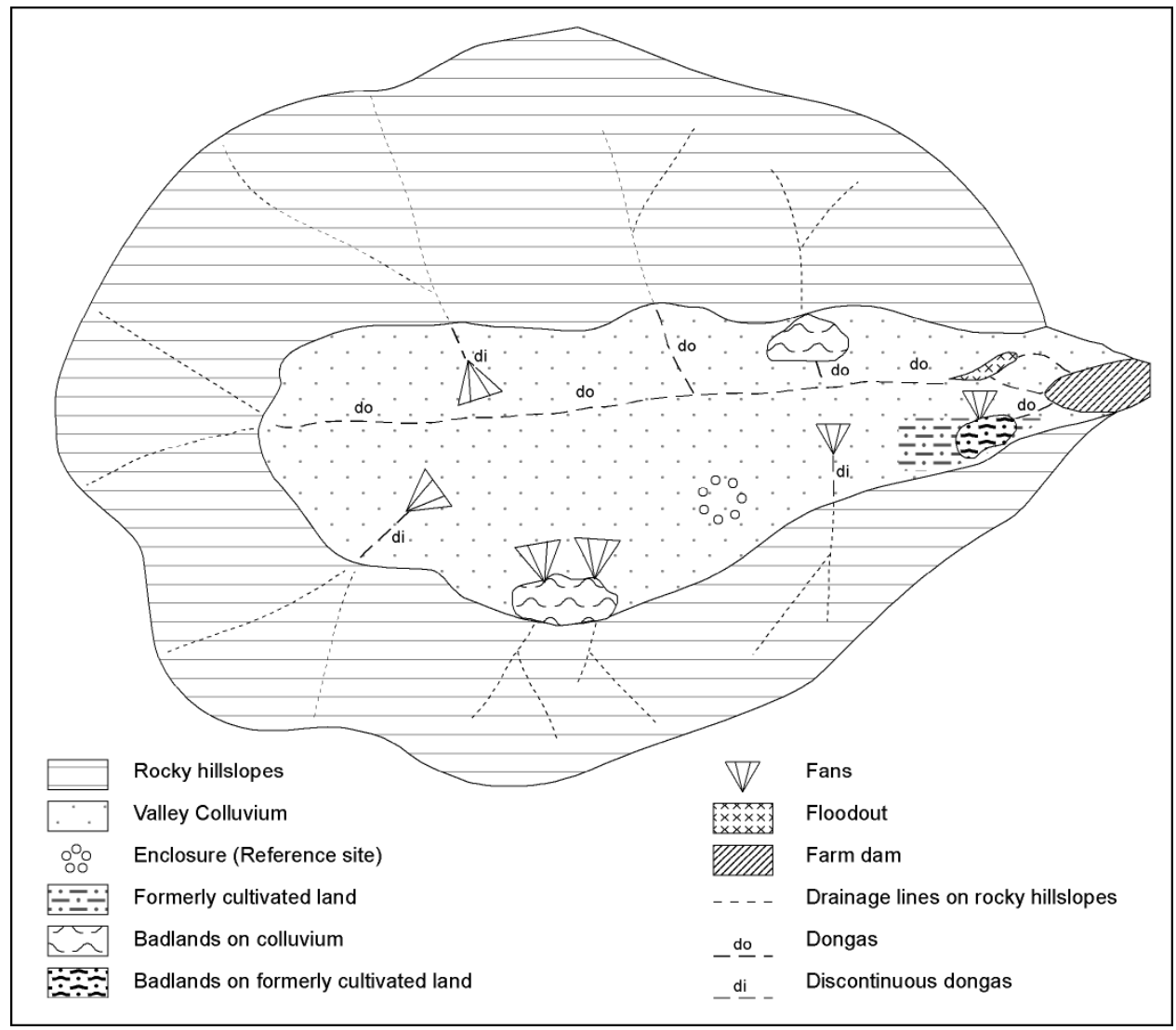

Figure 13.5 A conceptual model of catchment scale sediment budgets and connectivity in a typical South African landscape 


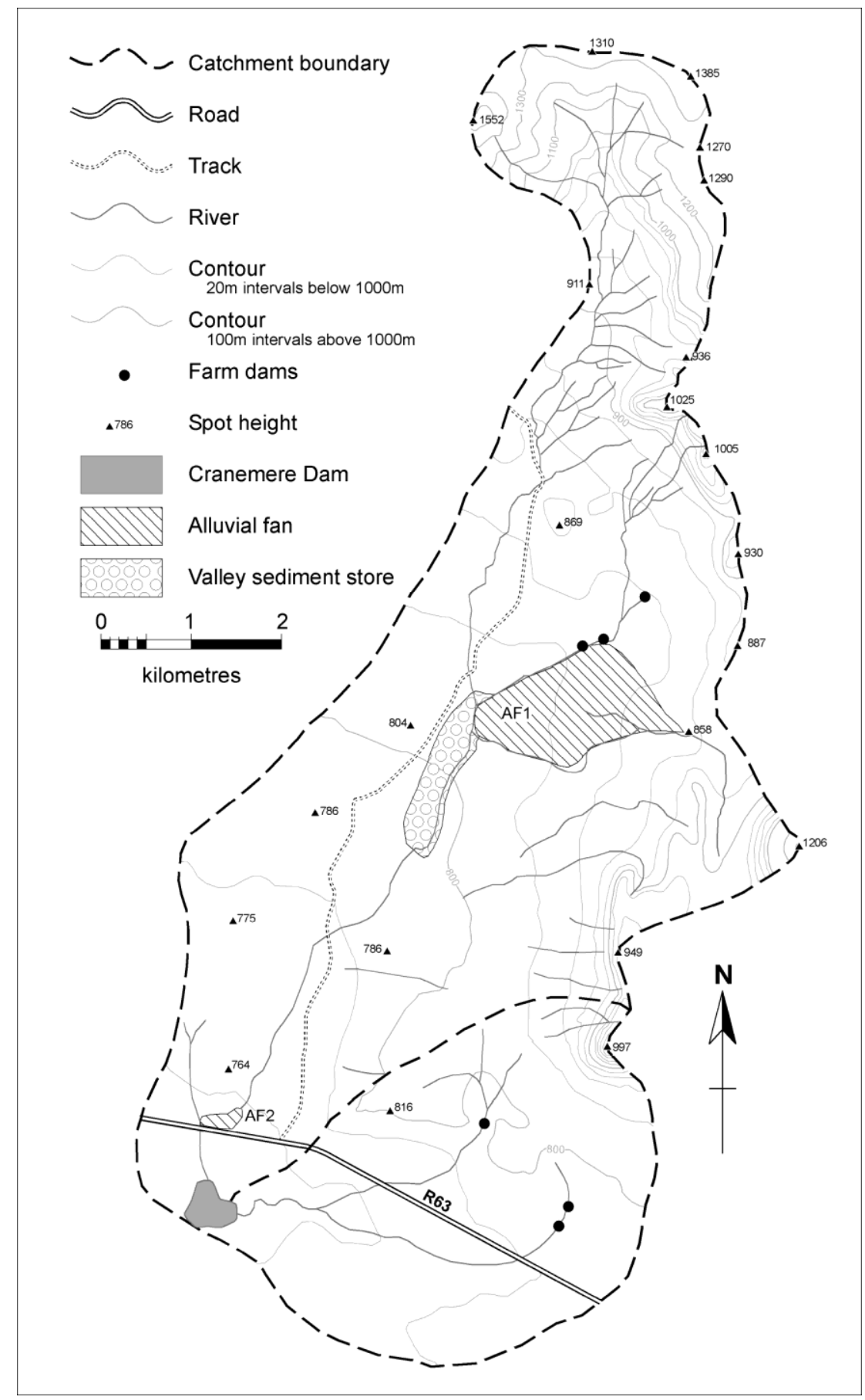

Figure 13.6 The Cranemere catchment showing the larger western and eastern sub-catchments; during high magnitude rainfall events, most sediment derives from the smaller eastern subcatchment 
